\title{
From Territory to Human Resources: A History of Colonial Adult Education in the Central Arctic
}

\author{
Scott McLean \\ University of Calgary
}

\begin{abstract}
This article narrates the history of state-organized adult education in the Central Arctic (Kitikmeot region) from the 1950s through the early 1990s. Prior to 1960, little formal adult education was delivered in the region, as relationships between Inuit and Euro-Canadians centred on the exchange of fox furs for external products. In the 1960s and 1970s, adult programs focused on housing, literacy, and home management, teaching groups of Inuit how to live in the permanent settlements that had recently been constructed by the federal government. In the 1980s, adult programs focused on employment preparation and life skills, moulding individual Inuit into employable citizens. This article addresses an important silence in existing scholarship regarding Canadian educational history, and sheds light upon the evolving priorities of Euro-Canadian colonizers in the Arctic; whether for purposes of territorial sovereignty or human resource development, adult education served as an important medium for the communication of colonial messages.
\end{abstract}

\section{RÉSUMÉ}

Cet article raconte l'histoire de l'éducation aux adultes organisée par l'État dans l'Arctique central (région de Kitikmeot), depuis les années 1950 jusqu’au début des années 1990. Avant 1960, peu de programmes d'éducation aux adultes étaient offerts dans la région, puisque les relations entre Inuits et Euro-Canadiens étaient alors centrées sur l'échange de fourrures de renard contre des produits venant de l'extérieur. Dans les années 1960 et 1970, les programmes pour adultes se sont concentrés sur le logement, l'alphabétisation et l'économie familiale, enseignant aux Inuits comment vivre dans les établissements permanents récemment construits par le gouvernement fédéral. Dans les années 1980, les programmes pour adultes se sont concentrés sur la préparation à l'emploi et les compétences de la vie quotidienne, façonnant les individus Inuits en citoyens aptes à l'emploi. Cet article comble un manque important dans la littérature sur l'histoire de l'éducation canadienne, et met en lumière l'évolution des priorités des colonisateurs Euro-Canadiens dans l'Arctique. Que ce soit à des fins de souveraineté territoriale ou de développement des ressources humaines, l'éducation aux adultes a servi comme un important moyen de communication des messages coloniaux. 


\section{Introduction}

Adult education was an integral part of the Euro-Canadian colonization of the Arctic. Studying the evolution of adult education programs provides unique insight into colonial priorities, since such programs were explicitly developed and delivered in order to mould Inuit in particular ways. In this article, I argue that the priorities of EuroCanadian colonizers in the Arctic evolved through three stages: resource extraction, territorial sovereignty, and human resource development. These priorities were clearly expressed and directly communicated to Inuit through the curricula and learning materials developed for adult education programs. I develop this argument through narrating the history of state-organized adult education in what was known administratively as the Central Arctic, or Kitikmeot region. The region had six main communities (see Figure 1), five of them (Cambridge Bay, Gjoa Haven, Kugaaruk, Kugluktuk, and Taloyoak) located on the coastline of what is now western Nunavut and one (Ulukhaktok) near the northeastern corner of the Northwest Territories (NWT). ${ }^{1}$

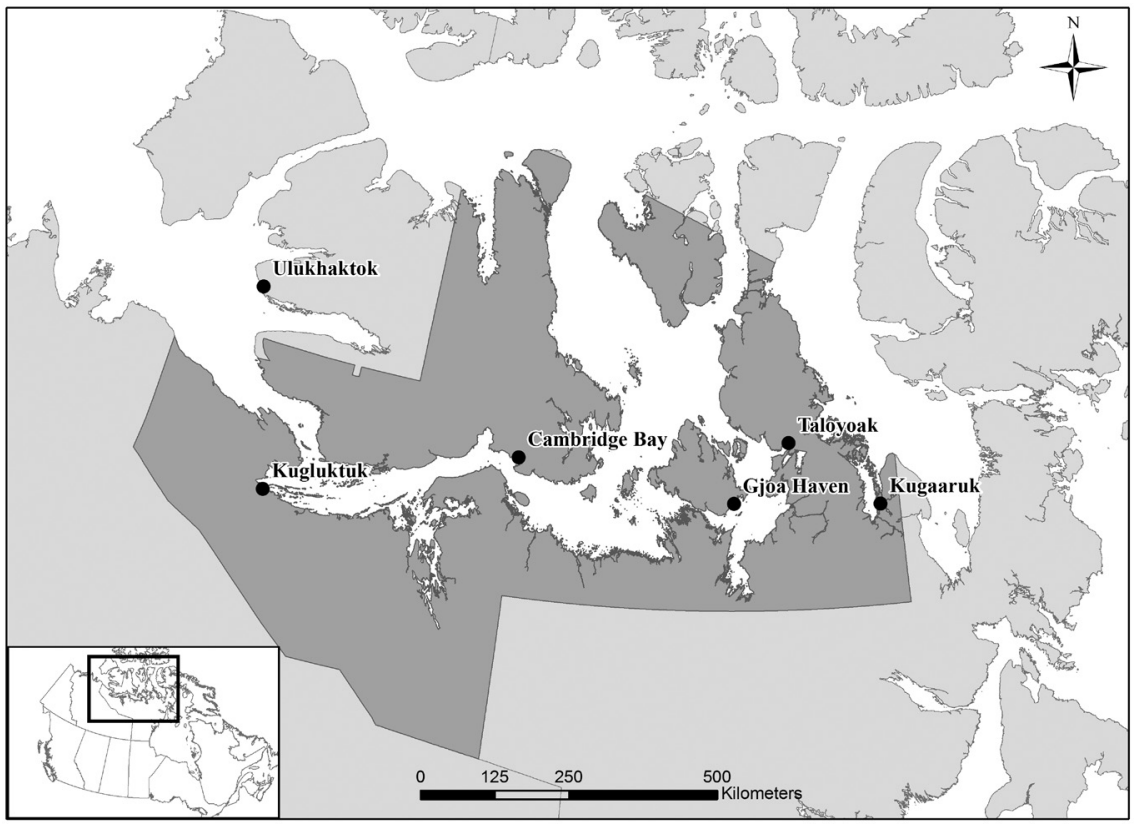

Figure 1: Kitikmeot Region, Nunavut

Source: Map produced by Peter Peller and Chris Smith, University of Calgary.

My history of state-organized adult education in the Kitikmeot begins when such programs were initially constructed as part of the emergence of a federally-operated school system in the 1950s and ends for two reasons in the early 1990s. First, in 1992, Inuit voted overwhelmingly in favour of a referendum to ratify the Nunavut Land Claims Agreement. By 1999, this agreement had led to the creation of the 
Nunavut Territory and a de facto form of self-government for the Inuit. Since the Nunavut Land Claims Agreement could be interpreted as a form of Inuit consent to becoming part of Canada, direct colonialism in the Arctic could be understood as ending in the 1990s. Second, also in 1992, Arctic College established a "made in the North" curriculum for adult basic education in the NWT. ${ }^{2}$ While such developments did not immediately lead to post-colonial forms of adult education, they did signal the beginning of important transitions, and they did make the period prior to 1992 a particularly important era for the study of colonial adult education.

Just as the period between the 1950s and the 1990s provides a useful focus for the study of the role of adult education in processes of colonization, so too does a focus on the Kitikmeot region. Due to geographical and climatic factors, the Kitikmeot was among the last places in Canada to have an ongoing presence of non-Indigenous people. Euro-Canadian whalers were never widely active in the region, and the first fur traders arrived in the Kitikmeot in $1905 .{ }^{3}$ The earliest recorded contact between representatives of the government of Canada and Inuit in the Kitikmeot took place during World War I. On July 18, 1916, Diamond Jenness, serving as an ethnologist with the Canadian Arctic Expedition, wrote to the Royal Northwest Mounted Police commissioner: "I have the honour of forwarding the following information concerning the so-called Central or Copper Eskimos, trusting that it may be of value should they be brought more directly under administrative control." " The late date of sustained Euro-Canadian contact with Inuit in the Kitikmeot makes the history of that region particularly interesting as a case study of colonization. Furthermore, to my knowledge, the region has not been the primary focus of prior research in educational history.

This article is based exclusively upon archival research. I spent a period of about six months at Library and Archives Canada, systematically reviewing records pertaining to the history of the Canadian government's administration of Arctic territories, with a special focus on the domains of adult education and children's schooling. Furthermore, I spent a period of about two months at a regional document warehouse maintained by the government of the NWT in Cambridge Bay, reviewing all available adult education records from Arctic College and the NWT Department of Education. While such research enabled the gathering of substantial data, it had two obvious shortcomings. The first was the existence of gaps in the archival record - particularly in the 1970s immediately following the transfer of responsibility for Inuit education from the federal to the territorial government. The second was the absence of Inuit voices in my historical data. This is an important limitation of my research, and therefore this article should be read as an interpretation of messages communicated by Euro-Canadian colonizers, rather than as a holistic interpretation of colonial encounters in the Arctic. My interpretation of this "top-down" historical data was not undertaken in the absence of contact with Inuit. Between 1989 and 1993, I worked as a community adult educator for two years in Cambridge Bay and for two years in Kugaaruk. My experiences as an adult educator in the Kitikmeot helped me interpret the data presented in this article, but were not directly part of my research. 
Following a brief literature review that locates my work within existing scholarship, I present a three-part history of adult education in the Kitikmeot, describing the evolution of programs and curricula and providing illustrations of learning resources employed in such programs. This history demonstrates that the priorities of EuroCanadian colonizers in the region evolved from resource extraction to territorial sovereignty and then to human resource development. This narrative is important both for historians and educators who wish to better understand past and present practices in adult education and for a broader audience of social scientists, public administrators, and political activists who wish to better understand the process of Arctic colonization and the role of educational programs in that process. The article thus offers an empirical portrait of an under-studied domain in Canadian educational history and shows how adult education programs provide insight into the messages that colonial authorities wished to communicate to their subjects.

\section{Literature Review}

This article is located at the intersection of two streams of scholarly writing: the history of Inuit education and the critical analysis of Euro-Canadian colonization of the Arctic. Substantively, my work extends existing research on the history of Inuit education by examining a geographical region that has received little prior attention and by focusing upon a domain that has likewise been relatively neglected in published scholarship: the formal education of adults. Heather E. McGregor ${ }^{5}$ and Ann Vick-Westgate ${ }^{6}$ have published ambitious manuscripts on the history of Inuit education. Both books give voice to Inuit experiences and present histories of learning and education over a period that extends from pre-colonial to post-colonial times. My study of the history of state-organized adult education during the colonial era is far more restricted in scope, method, and time period than the work of McGregor and Vick-Westgate, but it does extend their more comprehensive historical scholarship by providing a detailed study of a particular type of education in a particular place.

Little scholarly research has been published that investigates the history of Inuit adult education. Two exceptions include a recent article written by Sheena Kennedy Dalseg for a special issue on northern education in Historical Studies in Education/ Revue d'histoire de l'éducation, and my own previous publications, discussed below. Kennedy Dalseg narrates the historical evolution of policies and institutions relating to adult education in the Eastern Arctic, and she provides insight into the self-understanding of selected adult educators. She interprets this evolution in terms of the rise, fall, and potential rebirth of a "liberating model" of adult education:

Despite its origins as an instrument of colonial intervention, adult education has served as a means through which to promote and support local self-determination and imaginative community responses to social and economic development and change. Under the right conditions, it could do so again. ${ }^{8}$ 
from policies, institutions, and self-understanding to programs, curricula, and the messages contained in specific learning materials presented to Inuit adults. The article departs from Kennedy Dalseg's approach by focusing upon a specific region and by analyzing in greater detail the relationships between adult education and the evolution of the Euro-Canadian colonial project.

Analytically, my work contributes to the effort to interpret and explain the EuroCanadian colonization of the Arctic. The government of Canada has published at least three significant accounts of the history of relationships between Inuit and the state. ${ }^{9}$ Historians frequently locate the decade following World War II as the time during which Canadian government activity in the Arctic intensified and cite the following basic reasons for that intensification: threats to Canadian sovereignty posed by American military activities during World War II and the Cold War, technological advances in transportation and communications that led to the Arctic becoming more accessible, the broader expansion of welfare state measures across Canada, and the fact that the collapse of the fur trade led to very difficult living conditions for many Inuit. ${ }^{10}$ Scholarship concerning relations between Euro-Canadians and Inuit describes three key aspects of colonization in the Arctic. First, Inuit economic self-sufficiency was destroyed through a spiral of dependency that began in the eras of whaling and fur trading and intensified in the era of wage labour and welfare assistance. ${ }^{11}$ Second, Inuit cultural integrity was undermined through explicitly assimilationist state programs and the immigration of large numbers of Euro-Canadian managers, tradespeople, and professionals. ${ }^{12}$ Third, Inuit political autonomy was compromised through the constitutional and legal structures imposed by Euro-Canadian governments. ${ }^{13}$

Scholarship concerning the history of Inuit education has by no means been separate from the analysis of the Euro-Canadian colonization of the Arctic. McGregor observes in the works cited above that the establishment of formal systems for children's schooling involved the imposition of Euro-Canadian institutions, values, and languages. What has been missing from many accounts of the colonial period in the history of Inuit education is a rigorous analysis of the linkages between particular forms of educational intervention and the evolving strategies and priorities of colonial rule. In the parallel field of social welfare, Frank Tester and various co-authors have demonstrated how specific policies and interventions (from the relocation of Inuit to the High Arctic and the slaughter of Inuit sled dogs to the organization of professional social work practices) have been structured by, and have worked to support, broader colonial priorities (from ensuring sovereignty to expanding capitalist forms of social relations). ${ }^{14}$ My own publications, rooted in research conducted for my $\mathrm{PhD}$ dissertation, ${ }^{15}$ have contributed to the understanding of state-organized adult education as a component of colonization. These publications have addressed the evolution of discourses through which Euro-Canadian administrators and educators conceptualized Inuit education, ${ }^{16}$ the structure of adult educators' classroom practices, ${ }^{17}$ and educators' efforts to understand Inuit resistance to adult education. ${ }^{18}$ The contribution of the present article is to document the shifting priorities of colonial authorities and to illustrate how such priorities were communicated to Inuit through the medium of adult education. 


\section{From First Contact to 1960: Adult Education for Mercantile Times}

As noted above, the Kitikmeot was among the last places in Canada to have an ongoing Euro-Canadian presence. While explorers such as Samuel Hearne and John Franklin visited the region in the late eighteenth and early nineteenth centuries, ${ }^{19}$ and while ethnographers such as Vilhjalmur Stefansson and Diamond Jenness spent time in the region in the early twentieth century, ${ }^{20}$ it was not until the expansion of the fur trade following World War I that most Inuit groups in the region experienced sustained contact with Euro-Canadians. The Hudson's Bay Company opened the first permanent trading post in the region in 1916, and a decade later, at the shortlived peak of the fur trade in the Kitikmeot, a total of thirty-five trading posts were operating. ${ }^{21}$ Royal Canadian Mounted Police (RCMP) officers were the first government representatives to reside permanently in the Kitikmeot, with the first three police posts opening near Kugluktuk in 1919, in Cambridge Bay in 1926, and in Taloyoak in 1949. ${ }^{22}$ Missionaries soon joined fur traders and police officers in the region, creating a Euro-Canadian triumvirate. While some missionaries had been active near Kugluktuk as early as 1915, permanent Anglican or Roman Catholic missions were established in Kugluktuk and Cambridge Bay in 1929, Kugaaruk in 1935, Ulukhaktok in 1939, Gjoa Haven in 1951, and Taloyoak in $1954 .^{23}$

In the centuries preceding Euro-Canadian contact, adult learning in the Kitikmeot was widespread, but formal institutions of adult schooling were absent. Adults and children learned skills and knowledge from observation, informal instruction, and experimentation. Formal schooling did not begin in the early stages of Euro-Canadian contact. As Abele observed for the NWT in general, explorers, traders, and missionaries relied upon Indigenous people to survive. ${ }^{24}$ In the fur trade era, Inuit instructed Euro-Canadians on matters such as game distribution, ice conditions, geography, and Inuktitut, and the education of Inuit adults by Euro-Canadians was selective and limited. ${ }^{25}$ Traders, missionaries, and police officers typically selected a couple of Inuit to train as clerks, catechists, housekeepers, or general assistants. Some instruction occurred in the use and maintenance of new technologies such as rifles, steel traps, and outboard engines. However, prior to the mid-1940s, the policy of Canadian governments was to discourage the formal education of Inuit, ${ }^{26}$ and until 1950, there were no state-operated schools in the Kitikmeot. ${ }^{27}$

Over the course of the 1940s, the government of Canada began taking a more direct role in Inuit education. This policy change was signalled in a December 4, 1945, memorandum written by the deputy commissioner of the NWT, R. A. Gibson:

There have been many discussions in the past on the expediency of educating the Eskimos beyond a certain point for fear they would become dissatisfied with or unsuited to their mode of life in a region where the natural resources are limited and where there is little choice of location offered. However, the view is held by an increasing number of people, as the north becomes better known, that we should be doing more to give our Eskimo a sufficient knowledge of English and Arithmetic to enable them to transact their business with the traders more efficiently. ${ }^{28}$ 
As official interest in Inuit education grew, so did pronouncements about the inadequacy of the mission schools that had been operating in the Arctic. The following passage, from a May 17, 1949, précis for discussion by the NWT Council's SubCommittee on Education, illustrates the character of such pronouncements:

True, the individual missionaries may be sincere and may be devoting a considerable amount of time and energy to this work; they may each be satisfied with their results, but in the opinion of all the Government observers the missions have not and are not now supplying adequate educational facilities to the Eskimo people. ${ }^{29}$

As part of the broader transition from missionary to state-organized schooling in the Arctic, federal day schools were established in Kugluktuk in 1950, Cambridge Bay in 1957, Taloyoak and Gjoa Haven in 1958, Kugaaruk in 1962, and Ulukhaktok in 1965. The establishment of federal schools marked the beginning of state-organized adult education in the Kitikmeot. Through the 1950s, "welfare teachers" employed by federal day schools were expected to engage in adult education activities. Indeed, as the following anonymous report from March 1951 indicates, such teachers had very broad responsibilities:

It is the duty of these welfare teachers to develop the school as the vital centre of the community as a whole. It is used for meetings, games, social events, health clinics, organization and activities of clubs, as well as for more conventional forms of instruction... In addition, they are called upon to give particular attention to appropriate measures for adult education through encouraging the study of English, reading, sanitation, hygiene, handicrafts, and various worthwhile community activities. ${ }^{30}$

Within the Kitikmeot, the only adult education activities reported by welfare teachers in the 1950s were evening programs offered in Kugluktuk in 1954 and in Kugluktuk and Cambridge Bay in 1958 and 1959. These programs were held at most one evening per week, were sustained for only a few months at a time, and consisted primarily of film showings, English classes, and square dances. ${ }^{31}$

Given the scarcity of surviving documentation, it is difficult to reconstruct the content of adult education in the Kitikmeot in the 1950s. However, curricular resources from the start and end of the decade illustrate a profound change in the sorts of messages that Canadian governments wished to communicate to Inuit through the medium of adult education. In 1949, the Department of Mines and Resources published The Book of Wisdom for Eskimo in both English and Inuktitut. ${ }^{32}$ This educational resource was intended to help Inuit live successfully in a hunting and trapping economy. The introduction to the book explained:

The first part of this book is about how to be healthy and happy. When we have good food, warm clothes, good kind friends and no sickness we are 
happy... The second part contains advice about how to be prosperous, how the King is helping Eskimo children, how to make your rifles and boats last a long time, how to save animals from becoming scarce, and how to plan for times of scarcity. ${ }^{33}$

Part I, prepared by the Department of Health and Welfare, included sections on disease prevention and care; cleanliness of camps, igloos, air, water, food, dishes, and bodies; caring for babies; and "what to do when frozen." Part II, prepared by the Bureau of NWT and Yukon Affairs, contained sections on family allowances, care of boats and rifles, conservation of game, planning for periods of scarcity, and feeding babies. The Book of Wisdom for Eskimo instructed Inuit how to use Euro-Canadian technology and knowledge to thrive as hunters and trappers. Readers should not overlook the paternalistic tone and denigrating assumptions implicit in this resource; as an example, it is unlikely that many Inuit actually needed expert Euro-Canadian advice about dealing with a cold climate.

In stark contrast, a series of "Intensive Courses in English for Eskimos," developed by the Department of Northern Affairs and National Resources (DNANR) in 1957 and 1958, were explicitly designed to facilitate Inuit access to waged employment. ${ }^{34}$ The rationale for such adult education courses was explained as follows:

The next two years will likely be the critical period for integrating Eskimos into the Northern labour force. The type of jobs they are able to fill and their performance on the job will undoubtedly influence the scope and pattern of employment opportunities available to Eskimos for the next generation. Potential employers have emphasized that they are prepared to employ Eskimos if they have a "good working knowledge of English."

Given this rationale, the "Intensive Courses in English for Eskimos" focused on language instruction but also included content regarding employee rights and responsibilities; interacting with Euro-Canadians; wages, taxes, and unemployment insurance; spending money wisely; living in a permanent community (for example, sanitation, housing maintenance, health services, recreation, and schools); and home and family life.

Changing curricular materials reflected major political-economic changes in the Arctic. Within the Kitikmeot, the fur trade era lasted for only about thirty years. By 1950 , the number of fur trade posts in the region had dropped to nine, ${ }^{35}$ and by the mid-1960s, fur trading accounted for only about 15 per cent of cash income among Inuit in the region. ${ }^{36}$ During the fur trade era, relationships between Inuit and EuroCanadians were mercantile in nature: the Inuit became small commodity producers, trapping and trading fox furs to Euro-Canadians in exchange for goods such as guns, boats with outboard motors, fishing nets, food, and metal implements such as knives and sewing needles. These relationships changed dramatically with the collapse of the fur trade and the ensuing dependency of Inuit in the Kitikmeot on wages and unearned transfer payments from government for their survival. In the 1950s and 
1960 s, the great majority of Inuit in the Kitikmeot moved into one of six permanent settlements constructed by the federal government. With such settlement, the era of mercantile relationships between Inuit and Euro-Canadians essentially ended, to be replaced by an era of direct colonialism. Adult education programs, which had not been significant when Euro-Canadian interest in the Kitikmeot was focused on the extraction of resources (furs), became an integral part of the establishment and maintenance of colonial relationships focused on sustaining territorial sovereignty.

\section{0s and 1970s: Adult Education for Living in Permanent Settlements}

By the late 1950s, Euro-Canadians in the Arctic were disappointed with the slow development of adult education programs for Inuit. Numerous state officials requested that the DNANR organize adult education programs. These officials included school administrators who thought that children would be schooled more effectively if their parents had basic education; ${ }^{37}$ Distant Early Warning (DEW) line officials who thought that education would make Inuit employees more efficient; ${ }^{38}$ Welfare Division employees, who thought that adult education could help reduce the cost of Inuit social assistance; ${ }^{39}$ and Department of Transport officials, who thought that, with vocational training, Inuit could access jobs in air transport, telecommunications, and meteorology ${ }^{40}$ Interestingly, despite ample documentation of such EuroCanadian perspectives on the need for adult education to support colonial priorities, my archival research encountered no evidence of consultation with Inuit regarding what sorts of adult educational programs might be of interest to them. In 1960, the DNANR created an "Adult Education Section" — the first administrative agency with an explicit mandate to promote, support, and provide adult education in the Arctic. ${ }^{41}$ However, the impact of this administrative innovation was limited by the fact that from 1960 to 1963 the Adult Education Section had only one staff position to support programs throughout the entire NWT and Arctic Quebec. Commenting on the need for adult education in the Arctic, R. J. Orange, the administrator of the Mackenzie Region, complained on November 3, 1964, that "this is one aspect of our program which has not yet made any real impact." ${ }^{42}$

Throughout the Kitikmeot in the 1960s, teachers employed by federal day schools engaged in modest levels of evening adult education activities. From the NWT commissioner's Annual Reports, we know that the number of schoolteachers in the Kitikmeot increased from ten in 1963-64 to nineteen in 1967-68. Since two-thirds of federal schools in the NWT reported offering some form of adult education activities, ${ }^{43}$ we know that schoolteachers in the Kitikmeot offered informal evening programs for adults. Reports indicate that the topics of such adult programs included literacy, home management, and industrial arts. ${ }^{44}$ During the 1960 s, organizing and teaching adult education classes in the Kitikmeot was a voluntary endeavour. Classes were taught in the evenings, either by schoolteachers or by off-duty government employees, missionaries, or the spouses of such people. Classes were held in the federal school building, or at the home of the instructor.

The most prominent adult education programs delivered to Inuit in the 1960s 
were the Eskimo Rental Housing program and a series of functional literacy courses. For the NWT as a whole, the number of Inuit families participating in the housing education program peaked at 1,656 in 1969-70. ${ }^{45}$ While participation data specific to the Kitikmeot are not available, it is likely that a majority of Inuit adults in the region had at least some contact with the Eskimo Rental Housing program in the last half of the 1960s. The housing education program was administered by the Department of Indian Affairs and Northern Development (DIAND), which had assumed responsibility for Inuit adult education from the DNANR in 1965. In 1966, DIAND expanded its roster of adult education staff from two to fifteen people. ${ }^{46}$ The delivery of the housing education program in the Kitikmeot was enhanced by the fact that one of these new members of DIAND staff was a regional supervisor for Yellowknife, who assumed responsibility for promoting adult education in the Kitikmeot.

From 1966 to 1968, DIAND produced a variety of learning materials for the housing education program. ${ }^{47}$ Such materials included fifteen booklets: The Rental Collection System; The Housing Association Accounts; The Housing Association Council; The Stove and Heater; Living in the New Houses; Care and Use of Household Equipment; Safety in the New Houses; Renting and Buying a House in the North; The Government and Houses for Eskimos; The Rental Agreement; Paying Rent; Oil, Electricity, Furnishings; The Housing Authority; Before Moving; and Information for Interpreters.

In order to facilitate the adjustment to life in permanent houses, DIAND also produced worksheets and pamphlets in four supporting domains. First, since settlement diets were different from hunting and trapping camp diets, food and nutrition materials were produced. These materials explained the Canada Food Guide, each of the main food groups, elementary cooking instructions, table setting, using safe water, and using money to buy food. Second, since domestic chores were different in permanent houses than in igloos or tents, home management materials were produced. Detailed instructions were provided on how to wash dishes and clothes; clean floors, kitchens, bathrooms, appliances, walls, ceilings, and closets; make beds; and plan, delegate, and schedule household chores. Third, since permanent houses had more elaborate maintenance needs than temporary dwellings, home improvement and repair materials were produced. Such materials included instructions for making baby cribs, bunk beds, coat racks, curtain rods, tables, bookcases, gun racks, benches, shelves, and picture frames. Fourth, since making clothes with fabric was different than with furs, instructional materials in sewing were produced. These materials included instructions for making dresses, skirts, aprons, quilts, mats, drapes, and potholders. The Eskimo Rental Housing program and its various support materials explicitly facilitated Inuit adaptation to life in permanent settlements, and communicated Euro-Canadian norms and values as if they were technical rather than cultural in nature.

There were four courses in the Inuit functional literacy program developed in 1964: The Northwest Territories of Canada; The Family and Money; Co-operatives in the Northwest Territories; and Children of the Northwest Territories at Home and at School. ${ }^{48}$ Each course contained maps, filmstrips, pictures, teaching guides, and 
workbooks. "The Northwest Territories of Canada" was an elementary course in civics and social studies, with four stated principles:

1. That it is important that man is identified with the community, the Northwest Territories, Canada and the world.

2. That people should share in the development of the community, the Northwest Territories, Canada and the world.

3. That when people live together in a community, in the Northwest Territories, Canada, and the world there must be rules or laws.

4. That government, at various levels, provides a means by which people share in the development of the community, the Northwest Territories, Canada and the world.

These principles were developed through ten lessons on topics such as the people, administrative boundaries, and political institutions of the NWT. The core message of housing education and functional literacy programs for Inuit adults was clear: Inuit were encouraged to live in permanent settlements and to recognize those settlements as belonging to Canada.

Adult education expanded significantly in the 1970s with the transfer of administrative responsibility from the federal government in Ottawa to the NWT government in Yellowknife and with the appointment of educators dedicated specifically to programs for Inuit adults. The first full-time adult educators to be employed in the Kitikmeot were hired by the Continuing and Special Education Division of the NWT Department of Education in 1970 to work in Kugluktuk and Cambridge Bay. ${ }^{49}$ Kugluktuk had a full-time adult educator throughout the decade, while Cambridge Bay and Taloyoak had adult educators only in selected years. These adult educators taught adult basic education (ABE) programs and coordinated a range of other activities. In those communities without full-time adult educators, schoolteachers and other volunteers continued to provide some adult programming in the evenings. During the 1970s, communities in the Kitikmeot reported the following evening adult programs: Cambridge Bay — cooking, construction, film nights, first-aid, housing education, income tax preparation, Inuktitut, sewing, small business management, and typing; Gjoa Haven — sewing; Kugaaruk — basic English; Kugluktuk - communication skills, ceramics, cooking, film nights, first-aid, guide training, handicrafts, home management, income tax preparation, Inuktitut, money management, nutrition, prospecting, small engine repair, snowmobile maintenance, sewing, square dancing, story-telling, typing, and weaving; Taloyoak-cooking, first-aid, housing education, money management, sewing, and small business management; and Ulukhaktok - handicrafts, heavy equipment operation, home nursing, income tax preparation, reading, sewing, and typing. ${ }^{50}$

Over the course of the 1960s and 1970s in the Kitikmeot, adult education went from being an infrequent and informal experience to an extensive form of interaction between Inuit and Euro-Canadian state representatives. The government of the NWT summarized the changes to its provision of adult education in a 1977 report entitled Decade of Progress: ${ }^{51}$ 
Prior to 1967 adult education programs received a lesser priority in the total spectrum of education programs. There were some adult courses held at the local level, and most often these included the teaching of English as a second language, the three R's, and basic home-making. Usually taught by the community teacher after school hours, or by the wife of one of the employees of the government or private agencies like the Bay or the church, these courses were not integrated into any territorial-wide approach to adult education. The formal structuring of this program has been one of the major changes in the last ten years. Adult or continuing education is now properly funded, and there are now educators who are solely concerned with continuing education. Goals and policies have been defined to the extent that there is now a unified and systematic approach to the whole area of continuing education in the Northwest Territories.

By 1979, this "unified and systematic approach" included the following list of approved programs: ${ }^{52}$ Basic Job Readiness Training (ABE grades 0-5); Basic Training for Skill Development (ABE grades 5-10); General Education Development (ABE grades 10-12); Lifeskills for Adults; English as a Second Language for Adults; Nutrition Education; Housing Education; Consumer Education; Family Life Education; and Sewing/Textiles/Crafts. It also included the following approved learning materials: Northern Homes (1977); Northern Dollar (1978); Northern Nutrition (1978); Changing Lifestyles (1979); and Adult Basic Education Training Profile (1979). By the end of the 1970s, approved programs and materials consistently encouraged Inuit to be sedentary, literate, and employable.

The expansion of adult education in the 1960s and 1970s was integral to a much broader process of colonization. The changing ethnic composition of the region's population gives a simple indication of this process. In 1951, there were 61 EuroCanadians living in the region, representing 4 per cent of the total population of 1,442. ${ }^{53}$ In 1981, there were 365 Euro-Canadians residing in the Kitikmeot, representing 11 per cent of the total population of 3,240. ${ }^{54}$ This six-fold increase in the Euro-Canadian population represented a dramatic change in the daily experience of life for Inuit. Whereas Inuit life in the fur trade era typically involved only periodic contact with Euro-Canadian traders, missionaries, and police officers, Inuit life in the era of direct colonization involved daily encounters with Euro-Canadians (for example, schoolteachers, social workers, nurses, police officers, skilled tradespeople, municipal administrators, store managers, and missionaries) and their physical infrastructure (for example, houses, stores, roads, schools, nursing stations, municipal offices, airports, churches, recreational facilities, and systems for managing water, sewage, and garbage). Adult education was an explicitly assimilative strategy to facilitate the collective adaptation of Inuit to living in settlements administered by the Canadian state and to encourage Inuit to recognize such settlements as being part of Canada. 


\section{0s: Adult Education for Human Resource Development}

While the focus of Arctic adult education in the 1960s and early 1970s was collective and territorial (facilitating the occupation of permanent settlements by groups of formerly itinerant Inuit), this focus shifted in the latter 1970s and 1980s to being individual and cognitive (facilitating the employability of the individual Inuk). In the 1980s, adult education in the Kitikmeot expanded greatly, to become an extensive field of Euro-Canadian state intervention in Inuit life. Four communities (Cambridge Bay, Gjoa Haven, Kugluktuk, and Taloyoak) had full-time adult educators throughout the decade, while Ulukhaktok had one beginning in 1986, and Kugaaruk employed part-time adult educators on a seasonal basis beginning in 1985 . Community adult educators in the Kitikmeot typically taught a full-time academic upgrading program in the daytime, and coordinated part-time adult education programs that operated in the evenings. In the twelve-year period between 1979 and 1991 , a total of 421 adult education courses were delivered in the Kitikmeot, involving nearly 5,000 student registrations. ${ }^{55}$ Given a population of 2,458 people over the age of fifteen in $1989,{ }^{56}$ this means that each adult in the Kitikmeot would have participated in, on average, two adult courses during this twelve-year period.

For the first time ever, large numbers of Inuit adults in the Kitikmeot attended full-time adult education programs in the 1980s. From 1979 through 1991, a total of 1,283 individuals (more than half the adult population of the region) enrolled in one or more full-time programs of study. There were four main types of full-time programs: ABE (academic upgrading programs focused on reading, writing, mathematics, and life skills), in which 837 adults participated; skilled trades (vocational training programs, the most common being focused on carpentry or heavy equipment operation), in which 125 adults participated; basic office procedures (secretarial training programs focused on typing, filing, business mathematics, and communications) in which 105 adults participated; and life skills (focused on personal development and employment readiness), in which 66 adults participated. Smaller numbers of adults participated in a diverse range of other full-time, employment-oriented programs in areas such as business management, teaching, tourism, and hairstyling. The prominence of $\mathrm{ABE}$ and vocational programs reflected low levels of educational attainment among Inuit in the Kitikmeot. In 1989, no Inuk in the Kitikmeot had graduated from university, and only 2 per cent of adult Inuit had obtained high school diplomas. ${ }^{57}$

Part-time programs for adults were even more extensive and diverse than full-time programs. Records regarding part-time enrolments do not allow an accounting of how many individual adults participated; however, the 2,945 course registrations in part-time courses over the period from 1979 to 1991 were distributed as follows: 683 in employment preparation (for example, typing, computers, and bookkeeping); 598 in life skills (such as income tax preparation and parenting skills); 562 in home management (for example, nutrition, sewing, and cooking); 394 in academic upgrading (for example, literacy and ABE); 287 in Inuktitut; 214 in subjects of general interest (such as arts and crafts); and 207 in industrial arts (for example, woodworking and 
small engine repair). Part-time programs were typically offered in the evenings, between the months of September and April.

While enrolment statistics were not broken down by ethnicity, the vast majority of students in all categories of adult education programs in the Kitikmeot were Inuit. While Euro-Canadians composed 11 per cent of the region's population during the 1980 s, they formed a tiny proportion of the student body in adult education programs. Data are available for the ethnicity of instructors in 80 per cent of the adult education courses taught in the Kitikmeot in this period. Overall, approximately 77 per cent of adult courses were instructed by Euro-Canadians, 20 per cent by Inuit, and 3 per cent by a combination of Euro-Canadians and Inuit. With regards to specific types of courses, it is noteworthy that Euro-Canadians taught virtually all of the employment-oriented and skilled trades courses, 87 per cent of the life skills courses, and 83 per cent of the academic studies courses. The vast majority of adult education courses in the Kitikmeot during the 1980s had Euro-Canadian instructors and Inuit students.

While the ethnic division of labour in the Kitikmeot adult education classroom had a distinctively colonial character, what can be said of the nature of the instruction provided during the 1980s? The great diversity of instructors and courses involved and the absence of classroom observation data preclude a detailed characterization of what took place in most adult education courses. It is likely that a great many adult educators were sympathetic and sensitive to the circumstances and needs of their students. However, it is certain that the structure and curricular materials of many adult education programs, in the name of promoting employability, encouraged participating Inuit to embrace distinctively Euro-Canadian understandings of themselves and their lives. ${ }^{58}$ Two examples will illustrate this subtle process: the Tests of Adult Basic Education (TABE); and the Adult Life Skills Training Program (ALSTP).

The Tests of Adult Basic Education involved a series of nine, time-limited, multiple-choice exams (reading vocabulary and comprehension; mathematics computation, concepts, and problems; language capitalization; and punctuation, expression, and spelling), comprising a total of 315 questions to be answered in just over three hours. The number of correct scores on the TABE, which was provided in easy, medium, and difficult versions to accommodate the general level of proficiency of various students, was translated into a grade level of academic competency, corresponding to the standardized results achieved by California schoolchildren on each exam component. The role of TABE in adult education programs was succinctly described in its Examiner's Manual: ${ }^{59}$

TABE can be used to provide pre-instructional information about a student's level of achievement in the basic skills of reading, mathematics, and language; to identify areas of weakness in these skills; to measure growth in skills after instruction; to involve the student in appraisal of his or her learning difficulties; and to assist the teacher in preparing an instructional program to meet the student's individual needs. 
Throughout the 1980s, most students in academic upgrading programs across the Kitikmeot typically wrote the TABE at least once. ${ }^{60}$ Intake, mid-program, and exit TABE scores were used to quantify student academic progress during a program. TABE scores had practical significance in the Kitikmeot, since they were widely accepted as equivalent to more formal academic qualifications when applying for government jobs or for entry into vocational training programs, and since they were used to determine which full-time students would be eligible for training allowances paid by Employment and Immigration Canada.

While the TABE appeared to be a neutral tool capable of documenting and comparing the academic competencies of adults, its use in the context of the Kitikmeot had colonial implications at several levels. First, although the TABE was apparently edited for ethnic bias, student scores depended upon possessing a particular stock of cultural knowledge. Few Inuit in the Kitikmeot possessed this knowledge, and so many were disadvantaged when writing the TABE. The exam's reading passages and mathematics word problems referred to such exotic places and things as Hawaii, Egypt, American population growth, commission sales, and interest rates for borrowing money. Second, given the prevalence of low levels of literacy skills across the region, many Inuit writers of the TABE were presented with somewhat demeaning results that implied that they were comparable in abilities to elementary schoolchildren. Third, the TABE misrepresented socially constructed capacities as individual abilities by forcing students to independently confront a seemingly objective and neutral series of questions. These tests quantified individual strengths and weaknesses without any reference to the social context in which individuals developed such strengths and weaknesses. By asserting that any individual may compare his or her academic abilities with putatively normal distributions of such abilities, the TABE mystified the social nature of the definition of what skills constitute basic education and of the means through which people acquire such skills. Fourth, the process of the TABE encouraged Inuit adults to understand their own educational status and actions within an individualized, medical model of intervention. Through employing the TABE in their courses, adult educators would diagnose student abilities and weaknesses, have students recognize such abilities and weaknesses, prescribe pedagogical interventions to alleviate students' weaknesses, and measure student progress after such pedagogical interventions.

An individualized, medical model of adult education was also employed in the life skills courses that were a common feature of Kitikmeot ABE courses in the 1980s. In 1979, the NWT Department of Education produced the Adult Life Skills Training Program (ALSTP). This program contained four units - self-awareness, health, personal finances, and housing — and was the primary life skills curriculum available to adult educators in the Kitikmeot. The first two learning activities of the ALSTP encouraged people to self-diagnose certain aspects of their lives as objective, personal inadequacies. The "Life Skills Checklist" identified fifty potential problems - ten each relating to personal issues, family relations, leisure activities, employment conditions, and community involvement — and required students to indicate whether they did or did not possess the skills required to resolve such problems. As one example, 
item twenty-six suggested: "You've lost your job; you owe money; your wife says you drink too much; and your child is sick. Problems keep piling up. You know what to do and you do it." ${ }^{1}$ After completing all fifty such items on the checklist, each student completed a score sheet, on which he or she marked how many skills they possessed for solving each of the five categories of problems. Thus students not only identified their life skills needs; they also crudely quantified their ability to deal with various types of problems. In a similar manner, the "Life Skills Problems Checklist" identified 131 issues (for example, those related to housing, employment, health, and personal finances) and required students to indicate whether the issue described either "was, was not, or was sometimes" a problem in their lives.

Once students had identified their life skills needs, the ALSTP provided a five-step problem-solving strategy aimed at alleviating those needs: recognize the problem; define the problem; choose a solution; apply the solution; and evaluate the result. This strategy encouraged Inuit adults to name certain elements of their lives as problems and to pursue rational, individualized courses of action to remedy such problems. The ALSTP consistently encouraged students to interpret social problems as individualized life skills problems, abstracted from any sort of social or historical context. Problems were assumed to be an individual's own possession, and solutions were possible through rational, individual action. Such assumptions were ludicrous in the Kitikmeot, given the obviously collective nature of issues such as unemployment and crowded housing conditions. As one concrete example, in 1989 the labour force participation rate among the 2,136 Inuit over the age of fifteen in the Kitikmeot was 50 per cent, and the unemployment rate among labour market participants was 39 per cent. ${ }^{62}$ Better academic qualifications or life skills may have been the means for some individuals to obtain employment, but they could not feasibly have been so for the majority of those without paid work in the region.

\section{Conclusions}

In this article, I have made both empirical and conceptual contributions to the study of Canadian educational history. Empirically, I have brought to light an original narrative about the emergence and evolution of formal adult education in a remote and vast, but scantily populated, region of the Arctic. Conceptually, I have demonstrated that studying the history of adult education provides a unique perspective on the messages that colonial authorities (in this case, representatives of the government of Canada) wished to communicate to colonized subjects (in this case, Inuit living in the Kitikmeot). Such messages are evident in the curricula and learning materials produced for adult education programs.

The history of adult education in the Kitikmeot reveals three basic messages. First, during the period of mercantile exchange between Inuit and Euro-Canadians, the message implicit in the absence of formal adult education programs and in learning materials such as The Book of Wisdom for Eskimo was for Inuit to carry on being hunters and trappers. During the fur trade era, sustaining mercantile relations of exchange between Inuit and Euro-Canadian traders simply did not require direct government 
intervention in the education of Inuit adults. Second, during the period in which direct, colonial rule was being established, the explicit message of housing education and functional literacy programs was to learn to live in permanent settlements governed by Euro-Canadian institutions. This message had a territorial rationale: Inuit were to occupy the settlements that established the strongest possible claim to Canadian sovereignty over the Arctic, and they were to recognize such settlements as part of Canada. Third, during the later colonial period, in which life in settlements had become accepted as a feature of the Arctic landscape, the explicit message of academic upgrading, life skills, and vocational preparation programs was to learn to become employable and to have an individual rather than collective relationship to the government of Canada. This message had a human resources development rationale: Inuit were to become employable citizens and to recognize themselves as individually responsible for their success in doing so. From the 1960s through the 1980s, adult education was on the front lines of colony-building in the Kitikmeot.

It is important to note that colonial rule does not necessarily imply pernicious intentions or exploitative outcomes. With regards to the Kitikmeot, there is considerable archival evidence that state representatives in the 1950s and early 1960s saw the construction of permanent settlements as a responsible and humanitarian response to dire circumstances faced by Inuit in light of recurrent epidemics and depressed prices for white fox furs. Throughout the 1950s, RCMP reports referred to the issuance of emergency food and supplies to Inuit in the Kitikmeot ${ }^{63}$ and to critical shortages of food. ${ }^{64}$ An RCMP report dated February 1, 1960, gave the following grim statistics for the eastern half of the Kitikmeot for the calendar years 1958 and 1959: of sixty live births, twenty-six infants died in their first year of life; six people starved to death; measles killed five people; pneumonia and undetermined illness killed six people; one woman died in childbirth; four people drowned; and five died of "old age." 55 In early 1960, an influenza epidemic killed eight Inuit between Kugaaruk and Taloyoak, and caused twenty-two others to be evacuated to Cambridge Bay and Churchill. In a March 17, 1960, memorandum about this epidemic, the director of the Northern Administration and Lands Branch asserted that, out of 135 Inuit examined by medical personnel, none were healthy enough for hunting, trapping, or even "to care for themselves." 66 In a March 1960 report that outlined specific proposals to enhance the health and safety facilities available at settlements in the Kitikmeot, staff with the DNANR concluded:

The facilities outlined above seem to us the minimum necessary to avoid catastrophe when disasters recur, as they will. These provisions are still somewhat negative in that they do not provide any economic base for a standard of living which will make starvation obsolete, and medical crises rare. ${ }^{67}$

Permanent settlements were constructed in the Kitikmeot in part due to concerns for the well-being of the Inuit, and early adult education programs in housing education and functional literacy were logical and practical responses to the challenges faced by Inuit in their transition to life in such settlements. 
Just as vicious intentions did not trigger direct Euro-Canadian colonial rule in the Kitikmeot, economic exploitation was not a widespread outcome of such rule. In 1984, public sector wages accounted for 49 per cent of all cash income in the region, and unearned transfer payments from governments accounted for a further 10 per cent. ${ }^{68}$ Both private sector wages (39 per cent of cash income) and trapping (2 per cent of cash income) were typically dependent upon various forms of government subsidy. In 1986, income tax data show that two-thirds of adults in the Kitikmeot, and thus an even higher proportion of Inuit adults, earned less than $\$ 10,000$ per year. ${ }^{69}$ While a few profit-oriented, private-sector enterprises did exist, there was no widespread extraction of surplus value from Inuit labourers by bourgeois interests, nor has there been any significant extraction of natural resources from the Kitikmeot since the fur trade era.

The ambivalent nature of Euro-Canadian colonial rule in the Arctic was thoughtfully summarized by Diamond Jenness in 1964:

No other Canadian citizens, I think, receive so much aid, or enjoy so many privileges, without contributing far more heavily to their cost. It is true that the Arctic is a hard region in which no white man would voluntarily set up a life-time home and bring up a family; that if the Eskimos moved away it would be totally uninhabited, save for the workers at such mines as we judge profitable to exploit, and at the airfields, weather stations, and scientific outposts that we believe useful to maintain. Someday, perhaps, we will hire Eskimos to operate the mines for us, and to man the weather and scientific stations; but at the present time they lack the education and training. Even now, however, their occupation of the region contributes to our security, because one of their settlements is as valid a symbol of sovereignty as an army afield; and it can discourage foreigners (who may not always be friendly) from seeking to gain a footing in what we consider our territory... ${ }^{70}$

This passage both states the oft-repeated fact that Inuit were financial beneficiaries of Euro-Canadian colonial rule and reveals the oft-forgotten priorities of that rule: sovereignty over Arctic territory and the right to develop human and other resources within that territory. Such priorities, succinctly outlined above by a long-term federal civil servant and one of the most prominent Euro-Canadian observers of twentiethcentury life in the Arctic, were also clearly communicated by the history of colonial adult education narrated in this article. Such education began in earnest with efforts to ensure that Inuit effectively occupied settlements that would confirm Canadian sovereignty in the Arctic, and it later moved on to efforts to ensure that Inuit became employable citizens.

This article has argued that adult education served, at least in the case of the Kitikmeot region, as an important medium for the communication of colonial messages. Adult education programs explicitly communicated messages regarding sovereignty and human resource development, and they explicitly endeavoured to shape Inuit subjectivities along the lines of those messages. Further historical research could 
very productively explore the Inuit reception of such messages, and the degree to which such messages were embraced, resisted, and adapted in the process of that reception.

\section{Notes}

1 Note that during the period of history covered by this article, Kugaaruk was known as Pelly Bay, Kugluktuk as Coppermine, Taloyoak as Spence Bay, and Ulukhaktok as Holman. Note that while for the sake of simplicity I refer to these six communities as the Kitikmeot, the current boundaries of the Kitikmeot region (shaded in darker grey on the map) of Nunavut exclude Ulukhaktok.

2 This curriculum was published by Arctic College in 1992 in four volumes: (1) Instructor's Handbook; (2) English Program; (3) Math Program; and (4) Placement Manual.

3 Diamond Jenness, "The Cultural Transformation of the Copper Eskimo," Geographical Review 11, no. 4 (1921): 541-550.

4 Library and Archives Canada (LAC), Record Group (RG) 85, volume (v.) 571, file (f.) 244, part (pt.) 1 .

5 Heather E. McGregor, Inuit Education and Schools in the Eastern Arctic (Vancouver: UBC Press, 2010). Note that McGregor's scholarly publications on the history of Inuit education also include recent articles such as: "Curriculum Change in Nunavut: Towards Inuit Qaujimajatuqangit," McGill Journal of Education 47, no. 3 (2012): 285-302; "Situating Nunavut Education with Indigenous Education in Canada," Canadian Journal of Education 36, no. 2 (2013): 87-118; and "Listening for More (Hi) stories from the Arctic's Dispersed and Diverse Educational Past," Historical Studies in Education/Revue d'histoire de l'éducation 27, no. 1 (2015): 19-39.

6 Ann Vick-Westgate, Nunavik: Inuit-Controlled Education in Arctic Quebec (Calgary: University of Calgary Press, 2002).

7 Sheena Kennedy Dalseg, "Creating Citizens, Building Societies? Adult Education in the Eastern Arctic as if Community Mattered," Historical Studies in Education/Revue d'histoire de l'éducation 27, no. 1 (2015): 99-120. While less scholarly in nature, the following manuscript also provides an exception to the lack of historical work regarding Inuit adult education: Echo Lidster, Some Aspects of Community Adult Education in the Northwest Territories of Canada, 1967-1974 (Yellowknife: NWT Department of Education, 1978).

8 Kennedy Dalseg, "Creating Citizens, Building Societies?", 114-115.

9 Sarah Bonesteel, Canada's Relationship with Inuit: A History of Policy and Program Development (Ottawa: Minister of Public Works and Government Services, 2006); Richard Diubaldo, The Government of Canada and the Inuit, 1900-1967 (Ottawa: Indian and Northern Affairs Canada, 1985); and Richard Diubaldo, A Historical Overview of Government-Inuit Relations, 1900-1980s (Ottawa: Department of Indian Affairs and Northern Development, 1992).

10 William Morrison, "Canadian Sovereignty and the Inuit of the Central and Eastern Arctic," Inuit Studies 10, no. 1 (1986): 245-259; P. G. Nixon, "The Welfare State North: Early Developments in Inuit Income Security," Journal of Canadian Studies 25, no. 2 (1990): 144-154; and Morris Zaslow, The Northward Expansion of Canada, 1914-1967 (Toronto: McClelland \& Stewart, 1988).

11 Hugh Brody, The People's Land: Eskimos and Whites in the Eastern Arctic (Middlesex: Penguin, 1975); Robert Davis and Mark Zannis, The Genocide Machine in Canada: The Pacification of the North (Montreal: Black Rose, 1973); and Helge Kleivan, The Eskimos 
of Northeast Labrador: A History of Eskimo-White Relations, 1771-1955 (Oslo: Norsk Polarinstitutt, 1966).

12 John Honigman and Irma Honigman, Eskimo Townsmen (Ottawa: Canadian Research Centre for Anthropology, 1965); Robert Paine, ed., The White Arctic: Anthropological Essays of Tutelage and Ethnicity (Toronto: University of Toronto Press, 1977); J. I. Prattis and Jean-Philippe Chartrand, "The Cultural Division of Labour in the Canadian North: A Statistical Study of the Inuit," Canadian Review of Sociology and Anthropology 27, no. 1 (1990): 49-73; and Frank Vallee, Kabloona and Eskimo in the Central Keewatin (Ottawa: St. Paul University, 1967).

13 Frances Abele, "Canadian Contradictions: Forty Years of Northern Political Development," Arctic 40, no. 4 (1987): 310-320; Kenneth Coates, Canada's Colonies: A History of the Yukon and Northwest Territories (Toronto: James Lorimer, 1985); Kenneth Coates and Judith Powell, The Modern North: People, Politics and the Rejection of Colonialism (Toronto: James Lorimer, 1989); and Mark Dickerson, Whose North? Political Change, Political Development and Self-Government in the Northwest Territories (Vancouver: University of British Columbia, 1992).

14 Frank Tester and Peter Kulchyski, Tammarniit (Mistakes): Inuit Relocation in the Eastern Arctic, 1939-63 (Vancouver: UBC Press, 1994); Frank Tester, "Mad Dogs and (mostly) Englishmen: Colonial Relations, Commodities, and the Fate of Inuit Sled Dogs," Inuit Studies 34, no. 2 (2010): 129-147; Patricia Johnston and Frank Tester, "The Contradiction of Helping: Inuit Oppression(s) and Social Work in Nunavut," Journal of Progressive Human Services 26, no. 3 (2015): 246-262.

15 Scott McLean, "Producing a Society of Individuated Subjects: A Historical Sociology of Adult Education in the Kitikmeot Region, Northwest Territories" (PhD diss., Carleton University, 1994).

16 Scott McLean, "To Educate or Not To Educate? Canadian Discourses Concerning Inuit Schooling from the 1930s to the 1950s," Journal of Historical Sociology 8, no. 2 (1995): 182-197; Scott McLean, "From Cultural Deprivation to Individual Deficits: A Genealogy of Deficiency in Inuit Adult Education," Canadian Journal of Education 39, no. 4 (2016): 1-28.

17 Scott McLean, "Objectifying and Naturalizing Individuality: A Study of Adult Education in the Canadian Arctic," Canadian Journal of Sociology 22, no. 1 (1997): $1-29$.

18 Scott McLean, "Colonial Encounters in the Classroom: Adult Educators Making Sense of Inuit Resistance to Schooling," Studies in the Education of Adults 49, no. 1 (2017): $26-44$.

19 L. H. Neatby, "Exploration and History of the Canadian Arctic," in The Handbook of North American Indians, Vol. 5, David Damas, ed. (Washington, DC: Smithsonian Institute, 1984), 377-390.

20 Diamond Jenness, “The Copper Eskimos,” Geographical Review 4, no. 2 (1917): 81-91; and Vilhjalmur Stefansson, "Lessons in Living from the Stone Age," in Tribal Peoples and Development Issues: A Global Overview, ed. J. Bodley (Mountain View, CA: Mayfield Publishing, 1988), 33-42.

21 Peter Usher, Fur Trade Posts of the Northwest Territories, 1870-1970 (Ottawa: Department of Indian Affairs and Northern Development, 1971), 103-105.

22 Diubaldo, The Government of Canada and the Inuit, 15-22; G. Abrahamson, The Copper Eskimos: An Area Economic Survey (Ottawa: DNANR, 1963), 17; and D. Villiers, The Central Arctic: An Area Economic Survey (Ottawa: DNANR, 1968), 94.

23 LAC, RG 85, v. 1337, f. 600-1-1, pt. 11.

24 Frances Abele, Gathering Strength (Calgary: Arctic Institute of North America, 1989), 2-3.

25 David Keenleyside, "Arctic Learning: Education for the Adult Eskimo," Continuous Learning 5, no. 1 (1966): 29-32. 
26 McLean, "To Educate or Not to Educate."

27 Missionaries organized a modest level of formal education during the fur trade era in the Kitikmeot. Federal governments gave financial grants to Anglican and Roman Catholic missions to operate day schools in the following locations and years: Kugluktuk (1939-1946), Kugaaruk (1944-1946 and 1951-1959), Gjoa Haven (1952-1959), Cambridge Bay (1955-1956), Ulukhaktok (1954 and 1959), and Taloyoak(1956-1958). LAC, RG 85, v. 1506, f. 600-1-1, pt. 6; RG 85, 630 series.

28 LAC, RG 85, v. 1505, f. 600-1-1, pt. 2.

29 LAC, RG 85, v. 1130, f. 254-1, pt. 1 a.

30 LAC, RG 85, v. 1506, f. 600-1-1, pt. 3.

31 LAC, RG 85, v. 1266, f. 1000/145, pt. 5; LAC, RG 85, v. 1348, f. 1000/150, pt. 2.

32 Canada, Department of Mines and Resources, The Book of Wisdom for Eskimo (Ottawa: DMR, 1949). Note that this book was the focus of analysis in a previous scholarly publication: Paule McNicoll, Frank Tester, and Peter Kulchyski, "Arctic Abstersion: The Book of Wisdom for Eskimos, Modernism and Inuit Assimilation," Inuit Studies 23, no. 1-2 (1999): 199-220.

33 Canada, Department of Mines and Resources, The Book of Wisdom for Eskimo, 1.

34 LAC, RG 85, v. 1340, f. 603-5, pt. 1.

35 Usher, Fur Trade Posts, 103-105.

36 Abrahamson, The Copper Eskimos, 57, 87, 100, 114, 133, and 136; and Villiers, The Central Arctic, 146, 157, and 168.

37 LAC, RG 85, v. 1337, f. 600-1-1, pt. 10.

38 LAC, RG 85, v. 506, f. 690-1, pt. 10.

39 LAC, RG 85 , v. 1274 , f. $251-1-4$, pt. 1.

40 LAC, RG 85, v. 1235, f. 251-1, pt. 4.

41 Canada, Department of Northern Affairs and National Resources, Annual Report of the Education Division Concerning Education in the Northwest Territories and Arctic Quebec: 1963-64 (Ottawa: DNANR, 1964), 36-37.

42 LAC, RG 85, v. 1434, f. 600-1-1, pt. 20.

43 NWT Commissioner, Annual Report: Commissioner of the Northwest Territories, 19631964 (Ottawa: Queen's Printer, 1964), 11.

44 Canada, Department of Northern Affairs and National Resources, Annual Review of Education in the Northwest Territories and Arctic Quebec: 1964-65 (Ottawa: DNANR, 1965), 36; Canada, Department of Indian Affairs and Northern Development, Education Review: 1965-66 Northwest Territories and Arctic Quebec (Ottawa: DIAND, 1966), 44; Canada, Department of Indian Affairs and Northern Development, Education Review: 1966-67 Northwest Territories and Arctic Quebec (Ottawa: DIAND, 1967), 20.

45 NWT Commissioner, Annual Report: Commissioner of the Northwest Territories, 1970 (Ottawa: Queen's Printer, 1970), 97.

46 NWT Commissioner, Annual Report: Commissioner of the Northwest Territories, 1965 1966 (Ottawa: Queen's Printer, 1966), 15.

47 D. Simpson et al., "The Role and Impact of the Educational Program in the Process of Change in Canadian Eskimo Communities," in Educational Process and Social Change in a Specialized Environmental Milieu, ed. G. Gooderham (Edmonton: Boreal Institute, 1968), 1-41.

48 Canada, Department of Northern Affairs and National Resources, Adult Education Section, Adult Education Manual, Project Kits, Workbooks, Suggested Organization and Procedures (Ottawa: DNANR, 1964).

49 Lidster, Some Aspects of Community Adult Education, 43-46.

50 Information is derived from the Annual Reports of the NWT commissioner (19701972) and the government of the NWT (1973-1980). Reports of the commissioner 
were published in Ottawa by the Queen's Printer, while reports of the government were published in Yellowknife by the government of the NWT.

51 Government of the Northwest Territories, Decade of Progress (Yellowknife: Government of the NWT, 1977), 24.

52 Government of the Northwest Territories, Department of Education, Approved Programs and Courses (Yellowknife: Government of the NWT, 1979).

53 Canada, Northern Co-ordination and Research Centre, The Population of the NWT and Yukon, 1951-1961 (Ottawa: NCRC, 1963).

54 Northwest Territories, Bureau of Statistics, Population by Ethnicity, Region, and Community, June 1981 (Yellowknife: Government of the NWT, 1983).

55 Note that the comprehensive nature of the information regarding adult education in the Kitikmeot during this period is due to the fact that community adult educators, employed first by the Department of Advanced Education and later by Arctic College, were responsible throughout this period for submitting detailed monthly reports with information about programs, courses, and statistics regarding registrations. Data for this section of the article come from such monthly reports, along with course instructors' reports, and bi-monthly reports of the Arctic College vice-president for the Kitikmeot. All materials were accessed from an informal storage warehouse maintained by the government of the Northwest Territories in Cambridge Bay. Records were not organized in an archival manner, but rather simply stored in cardboard boxes.

56 Northwest Territories, Bureau of Statistics, 1989 NWT Labour Force Survey: Labour Force Activity, Education, and Language (Yellowknife: Government of the NWT, 1990), 60.

57 Ibid. Note that 14 per cent of Inuit had obtained some form of certificate or diploma, but that the vast majority of such credentials would not have been at the post-secondary level.

58 A detailed analysis of adult educators' practices in these years is provided in Scott McLean, "Objectifying and Naturalizing Individuality."

59 Patricia Lyster, Tests of Adult Basic Education: Examiner's Manual (Monterey: McGrawHill, 1976), 1.

60 Note that my knowledge of the role of the TABE and the ALSTP in this era reflects the fact that I worked from 1989 through 1993 as a community adult educator in the region.

61 Northwest Territories, Department of Education, Adult Life Skills Training Program (Yellowknife: Government of the NWT, 1979).

62 Northwest Territories, Bureau of Statistics, 1989 NWT Labour Force Survey, 60.

63 LAC, RG 85, v. 1475 , f. $253-1$, pt. 5 and 7.

64 LAC, RG 85, v. 1119, f. 1000/150, pt.1; LAC, RG 85, v. 1266, f. 1000/145, pt. 5.

65 LAC, RG 85, v. 678, f. A252-5/165, pt. 1.

66 LAC, RG 85, v. 746, f. A1000/165, pt. 1.

67 Ibid.

68 Northwest Territories, Department of Economic Development and Tourism, Kitikmeot Region Economic Base Study (Yellowknife: Government of the NWT, 1985), 116 and 147.

69 Northwest Territories, Department of Economic Development and Tourism, Kitikmeot Region Economic Facts (Yellowknife: Government of the NWT, 1989), 16.

70 Diamond Jenness, Eskimo Administration. Vol. II: Canada (Montreal: Arctic Institute of North America, 1964), 156. 